\title{
Future Tasks of the International Calvin Research
}

\author{
W H Neuser \\ Ostbevern, Germany \\ Secretary: International Congress on Calvin Research
}

With the word international, we think specifically of the worldwide research on Calvin. The term international also points to the international Calvin Congresses, of which, until now, six have been held. At the Congresses we try to combine the international research as well as to give a fresh impetus for research. The lectures of all the previous Congresses have been printed, with exception of the last Congress in Edinburgh, 1994, which is now being printed. The results of these Congresses are therefore easy to obtain - everyone can read them.

The task leads to a double question: 1 . Which topics of Calvin research have been analysed and discussed succesfully until now? 2. Which topics should urgently be researched in future?

The first answer includes both a review of the previous six Congresses as well as a glance at recent Calvin literature; the second answer will be developed in the overview which follows, titled The future tasks of Calvin research.

\section{THE REVIEW}

As a student at Göttingen university I attended the lectures and seminars of Otto Weber, the famous Calvin scholar and translator of Calvin. It impressed me that he praised of the seven large-sized volumes of E Doumergue, Jean Calvin (1899-1927). At the time, it seemed to be the fulfillment and the end of all Calvin research. Later on I noticed that Doumergue described the street, where Calvin lived in Geneva in 400 pages, but the world of ideas was not described in a conclusive way, not to mention in a final way. I realized that much more had to be done.

Three reports on the present state of Calvin research have been given at the European/International Congresses - by D Nauta; E Saxer and R C Gamble. They provided critical evaluations of the published studies and also pointed out the urgent tasks of Calvin research. They are worth reading again.

At the start of the Congresses the historical effects (Wirkungsgeschichte) of Calvin's work were treated. Remarkable is M Bucsay's lecture on Calvins Präsenz in Ungarn or B G Armstrong's dealing with the struggle on the Genevan Bible of 1588. The historical effects of Calvin (Wirkungsgeschichte) was dropped later on, because it yielded little in understanding of Calvin. Oddly enough, only a small echo arose from P Denis's lecture Calvin et les égliuses d'Etrangers au XVle siècle: Comment un minis- 
tre intervient dans une égise autre que la sienne. I do not understand this because Calvin worried about these refugees in Germany and the Netherlands as long as he lived.

We are now at an important point: Calvin's biography. At every Congress we have tried to discuss a part of his live; that is, we tried to describe the status of the research, and we also exposed the defects and gaps in Calvin's biography. In Hungary in 1986 B Roussel initiated this part of the Congress' program and spoke on Francois Lambert, Pierre Caroli, Guillaume Farel ... et Jean Calvin (1530-1536). In Grand Rapids in 1990 H A Oberman lectured on Initia Calvini (1525-1535), R Hörcsik on John Calvin in Geneva (1536-1538), and C Augustijn on Calvin in Strassbourg. Now the first years of Calvin's work in Geneva after 1541 could follow. All of these lectures gave a great insight on individual works, but they were not reports on the status of research on Calvin's biography, and did not reveal the lacunae in the literature. What we need, is a new, big biography on Calvin. Let me compare this situation with the research on Karl Barth.

We have some thousand monographs on Barth's theology and ideas, but only a comparatively small biography by Eberhard Busch. There is a danger of biographical docetism. How Barth's biography influenced his doctrine is not clear. The events in Barth's life and his experiences are rarely used to explain his theology. To put it in terms of Christological docetism: the doctrine has only a soul and no body and is therefore no longer historical. There is a similar danger in Calvin research if we have no modern biography, showing us all the details of his life.

A permanent theme is Calvin as interpreter of the Bible via commentaries and sermons. The reason for observing this theme is that Calvin's Institutes are overemphasized. The teaching of the Institutes suppress his ideas in his other writings. It seems that everything is clear and definite in the Institutes. But this is untrue in two regards. Firstly, this work of Calvin does not contain all his doctrines. For example: he treats his understanding of the Bible only partially, namely the Divine authority of the Bible (Inst I:6-9); Old and New Testament (Inst II:9-11) and the relation of ecclesiastical authority and scripture (Inst IV:8:1-9). There are more statements with regard to the Bible in his commentaries and sermons. Secondly, B G Armstrong raised the question at the South African Calvin Congress 1984, whether the Institutes are a kind of dogmatics, as most researchers think, or instructions to understand the Bible, combined with pastoral guidances. Armstrong is in favour of the second possibility. If the Institutes are not truely a dogmatics, they will not treat all doctrines evenly and completely. In this case, the Institutes are only one of Calvin's scripts, however the most important one. The other scripts have to be used to understand Calvin's theology. 


\section{* Calvin and the church fathers}

These themes have been studied often in the seminars of the last Congresses:

- Calvin and Bernhard of Clairvaux

- Calvin and Eusebius von Caesarea

- Calvin and Cyprian.

I doubt that Calvin understood the church fathers as independent theologians. Didn't they serve him as additional evidence to support his doctrines, which he in turn took from the Bible? In his time the church fathers had some authority, which Calvin did not want to leave to the opponents. It was more so that the church fathers in general were consulted for their opinion. An exception is Augustine, the most influential theologian of the early and medieaval church. His ideas were also the nearest to the reformation. In the debate over Communion, the church fathers are used as a kind of quarry, where we find the stones to fit our arguments. This is true for all of the members of the conflict over the Lord's Supper, Reformed and Lutheran.

* Calvin and the theologians of Scholasticism

In this field, Calvin research has made the least progess. This is not coincidentially. Until now, it is unsolved as to which 'school' Calvin belonged. Was he Thomist, Occamist or Scotist? John Maior is obviously excluded. Many researchers (T F Torrance, $\mathrm{K}$ Reuter and others) have tried to explain Calvin's theology in the light of Maior's influence. H A Oberman proved that Maior was not in Paris at the same time that Calvin studied there. In my opinion, there are very good reasons why we can not say to which school Calvin belonged. Although he studied Scholasticism, this way of thinking was overcome by stronger influences later on. After Scholasticism he turned to Humanism, as tought by Erasmus of Rotterdam. Erasmus was an opponent of the subtleties of Scholasticism and therefore Calvin was also. The opinions of the old writers - Greeks, Romans and the Biblical writers - were sought. Then the Reformation took over and the Bible became the only authority. It would be good to uncover this deeper layer, but until now there has been found no way to do it.

\section{* Calvin and his contemporaries}

This theme is often and in detail treated in areticles and monographs. Bullinger, Farel, Viret, Beza, Melanchthon, Bucer and others have been researched in their relationship to Calvin as well as the other way around. 
* Again and again the single theological Loci have been analysed. The doctrine of predestination of Calvin and Bucer (W van t'Spijker), the first article of the Creed according to Calvin (R Staufer); Semen fidei of Calvin (O Gründler) et cetera. But the praesidium of the International Congress was very cautious to put the single Loci on the program, because one does not want always to repeat studies of the Institutes. Therefore, $\mathrm{R}$ Staufer researched the doctrine of creation (God the Creator and keeper of the world) in Calvin's sermons. W van t'Spijker analysed the influence of Bucer on Calvin. Was Bucer perhaps Calvin's teacher?

* New themes or newly-treated themes

They were always found again:

- Calvin as polemicist (F M Higman, Chr.Partee).

- The tradition of the Institutes in the Calvin disciples (O Fatio).

— Did Calvin teach a 'light doctrine of modalism on Christology? (H.-H.Eßer).

- Calvin on penance as discussed in the sessions of the Council of Trent $(\mathrm{H}$ Schützeichel).

- Geneva in the sermons of Calvin (R Peter).

- Calvin as Law-giver, the constitution of the city of 1543 (R Kingdon).

Resumed were old themes such as

- Calvin and the modern economy (H.-H.Eßer), better known under the title:

Was Calvin the father of Capitalism?

- Calvin and Humanism (C Augustijn), et cetera.

\section{TASKS OF RESEARCH IN THE FUTURE}

Reports of research should be given in the later Congresses to come. It is indispensable that we draw summaries of the results of research in regular intervals. Since Calvin research has been growing at such a tempo - especially in the United States - it will be better to give reports on single sections of the research; for instance new biographies, editions, translations et cetera.

An urgent request is a big, new biography on Calvin. It can only be written by experts in French, except for Calvin's three years in Strasbourg and his relations to foreign personalities and churches.

We lack a book on Calvin and his opponents. These persons, like Georgius Siculus, the Anti-predestinarian, are not known to all of us. In Luther-research they have the book Die italienischen Gegener Luthers, of Friedrich Lauchert. 
In connection to this, we must mention that we do not have any knowledge of some important topics, for instance of the funeral services in Geneva. What the Institutes contain about Ordination, has been overestimated by A Ganoczy: According to the ecclesiastical ordinances of 1541 und 1561 there was no ordination at all. A D Pont has brought some light on the subject of the Confession of Faith by the youth before being allowed to attend Communion. But we don't know enough about this field. In fact, we do not know nearly enough about the daily spiritual life of the people in Geneva.

\section{NEW THEMES}

\subsection{Calvin's Epistomology}

This theme has not yet been investigated and described. I do not mean the theological epistomology, because It can be understood from the teaching of God and Man already (Inst $\mathrm{I}: 1: 1$ ). Neither do I think of Calvin's natural knowledge of God, because this has been cleared already by the disciples of Emil Brunner and Karl Barth after their famous argument of 1934.

But I can not answer the question: What is Calvin's general epistomology? Especially the question about Calvin's dynamical and/or static thinking needs to be explained. For instance, the reality of the Kingdom of God may explain this dynamic, actual thinking. Firstly, the Kingdom of Christ is a dynamical one because it develops until it is definitely realized only at the Last Day. It is growing eschatologically. Secondly, the Kingdom is today built up by proclamation, that is, by action. Some would ask: 'What is the Kingdom of God'? But it must be described in terms of actions and not ontologically. The question is: 'Does Calvin speak more in terms of action, or in static terms'? Calvin's doctrine of the four offices as such is very handy and convincing. But it is possible that we interpret it by static terms which leads to misunderstandings.

We will have to clear up our understanding of Calvin's logic, for example his use of syllogism (Syllogismus practicus) of his combination of knowledge and will (cognitio et voluntas/affectus), in other words, the ability of the human soul.

Here we can take a look at F L Battles article on Calculus Fidei of Calvin, that is his constant splitting off the terms as true or false. I am not sure whether Battles is right or not, but his article is worth looking at.

Calvin's theological epistomology can only be described fully when his general epistomology has been made clear. The way A Ganoczy and T F Torrance did it is unsatisfying, because what we want is Calvin's relation to philosophy (Plato, Aristotle, 
Greek and Judaistic thinking). Historically seen, it is the same question: 'To which school did Calvin belong to as a student, and which progesses in epistomology did he make later-on in his life?

\subsection{Theological terms}

By analysing them, we can get a new access to his theology. In Edinburgh, 1994, the term pietas was treated in one seminar and I want to direct the attention to this field. The term of piety in Calvin does not mean faith, but it is a forestep to faith. We can get new results, when we observe the terms in the connection, which they have in the single texts. We should treat them as if we do not already know what they mean. We should evaluate every term critically. Calvin often used the same term but with different meanings. Terms like religio, poenitentia, contritio et cetera should be investigated because they can give a cross-section of Calvin's way of theological thinking, as well as a test to see if we understand the Institutes correctly. A special example are the terms labyrinthus and abyssus.

W J Bouwsma interprets these terms in his book John Calvin and they should urgently be re-examined.

One difficulty is that we have only short indices of terms: One is at the end of Tholuck's Edition of Calvin's commentaries, as it was taken from the Amsterdam edition of Calvin's works, and a second one is given in Corpus Reformatorum vol 22 and 59. F L Battles also published a concordance of the latin Institutes, based on the Opera Selecta, which is indispensable to the researchers. The publishing house Droz may give out disks with the publication of the Opera Omnia, of which there has been, until now, only three volumes published.

\subsection{Calvin and the Apocalyptic texts}

As we all know, Calvin never explained the book of Revelation, but in $1990 \mathrm{E} \mathrm{A}$ de Boer gave a seminar on Calvin's sermons of Ezechiel 37 and 38, where the prophet gives apocalyptic prophesies. Calvin used the term figure (figure), parable (similitude), vision (visio) to interpret this apocalyptic prophecies. That means that to these terms an explanation must be added, as one does in the distribution of the sacraments (sacraments). The visions in themselves are dark without explanation. But what does this mean practically? Are they to be explained by other biblical words? I do not know. These are some of the difficult questions on Calvin's Hermeneutics, which are still unanswered. 


\subsection{The doctrine of the Lord's Supper and the doctrine of the ministry}

The doctrine of the Lord's Supper and the doctrine of the ministry have to be examined again under the aspect of static and dynamic thinking. In Edinburgh, M Márkus examined the ministry in the Institutes of 1536. He explained that the term ministry (ministerium) is used once only, because Calvin rather used many verbs to explain the duty of the minister. Today we like to use words such as pastoral care, church discipline, church goverment, office, et cetera. They are objective and help us to give correct definitions. I think that Calvin wants to speak about the actions of ministers and their obedience to the Lord's orders, rather than looking for general terms. Was Calvin thinking in objective categories or of actions leading to some goal?

In the same way Calvin's doctrine of the Lord's supper should be researched with the question: 'Does Calvin ask whether the bread and wine are the body and blood of Christ', or does he think of what happens when bread and wine are distributed to the congregation? In the European tradition we ask in the Aristotelian way, that is ontologically: 'What is on the altar', and we ask not in the Jewish way: 'What happens to the participants'? The New Testament thinks in a Jewish way, that is in the way of the Old Testament. And Calvin?

\subsection{The pecularity of Calvin's sermons}

The pecularity of Calvin's sermons should be researched. In 1551, as the Bolsec process was going on, he wrote the book De praedestinatione (known as Consensus Genevensis) and gave a sermon on predestination at the meeting of the Congrégation on the 18th December 1551. It is therefore possible to compare his sermon and his systematic teaching. How did he speak to the congregation about predestination? Are there any theological differences? I answer yes as it will be seen somewhere else. Anyway, we will have to study his sermons more carefully, especially the doctrinal ones.

\subsection{Some theological Loci are not treated satisfactorily}

\section{The doctrine of providence}

* The doctrine of providence: it is examined well in the Institutes, but what does he teach in other scripts?

* His doctrine of God should be reviewed under the viewpoint deus a se and God in his revelation. And how much did Calvin emphasize the deus a se? Did he think in the same way as he got older? According to Institutes I:1:1 the knowledge of God and the knowledge of oneself belongs together, but why then does he teach deus a se? 
* It was sensational when R M Kingdon reported at Edinburgh 1994 on the protocolls of the Genevan Consistory. They have been neglected badly until now. The protocolls of the first consistoires are now in print. They will have to be studied carefully. In them, many aspects of life are treated: Catholic ceremonies, economical regulations of the Senate, church discipline, forgivenes, et cetera.

* Calvin's doctrine of the two goverments. In my opinion, this doctrine has been researched too much under the aspects of the modern state and of the doctrine of Martin Luther. Calvin must be understood from his own thought.

With this, I end the list. We all know that there are other themes which have to be treated, and I do not give a final list. I only want to give impulses for further studies. 